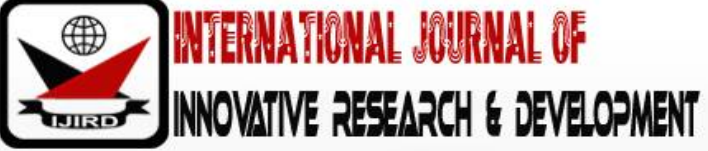

ISSN 2278 - 0211 (Online)

\section{Chinese Leader, Islam Majority and the Clash of Civilization: A Study of Muslim Acceptability of Chinesse Governor}

\author{
Morissan \\ Associate Professor, Department of Fakultas Ilmu Komunikasi \\ Universitas Mercu Buana, Indonesia
}

\begin{abstract}
:
This study aims to find out whether Muslims in Jakarta acknowledge the success of Basuki Tjahaja Purnama or Ahok as the Governor of DKI Jakarta for the period 2014 - 2017? Ahok is a Christian of Chinese descent. Research pays attention to Muslims who recognize Ahok's success. In the case of success being recognized but refusing to vote again is an indication of non-tolerant attitudes and clash of civilization as Samuel Huntington's (2009) thesis. But if they choose then it shows a tolerant attitude. The research method used is a survey with a questionnaire accompanied by structured interviews. A sample of 503 respondents who reside in Jakarta was chosen purposively with the criteria of educated religious Muslim women. The results showed that 48.7 percent of respondents said they would not vote for Ahok as Governor in the DKI Jakarta Regional Election in 2017, and thus the number of religious Muslim women who experienced a clash of civilizations was $48.7 \%$ which meant showing a moderate clash level.
\end{abstract}

Keywords: Ahok, Islam, benturan peradaban, Cina, politik

\section{Introduction}

This study aims to determine the attitude of religious Muslim women in Jakarta towards the incumbent Basuki Tjahaya Purnama, or more popularly called Ahok, as a non-Muslim governor in the Jakarta Regional Head Election in 2017. Ahok is a Chinese but very popular because of his success in building the capital city of Jakarta. He showed many achievements and received various awards. This study chose Muslims as respondents because Islam is the majority religion in the city. Also, certain Islamic groups considered hard-liners frequently voiced racist campaign to reject Ahok due to his different religion and race with the majority of Muslims in the city. Muslim hard-liners demonstrated their rejection in various mass media, especially social media.

The emergence of the racism issues ahead of the 2017 gubernatorial Jakarta elections raised questions about the acceptance level of Muslims towards non-Muslim leaders. Specifically, this study chose religious Muslims because it wanted to truly measure the true Muslim attitude, namely those who are serious about practicing their religious teachings while measuring their tolerance level towards their leaders of different religions and beliefs. Besides, the reason for choosing Muslim women as research subjects is because women are more easily identified in terms of their religiosity compared to men based on the clothes they wear, wearing hijab or headscarves.

This research was built on the assumption that religious Muslim women who recognize Ahok's success were not at ease with supporting him for the governor. This is due to the desire to choose professional leaders and achievers would clash with religious sentiment. Choosing leaders with the same religious background was preferred by Muslims as voters. So, who will win between tolerance and Islamic sentiment?

\subsection{Clash of Civilizations}

The recent radicalism and terrorism movements at the national and international levels raise questions about the readiness of the world's Muslim community to face the current global developments. The negative stigma for Muslims began to emerge especially since the terrorist attack by a radical Islamic group in New York City and Washington, D.C., the United States on September 11,2001, or known as 9/ 11.

The events of September 11 and various anti-western radical movements emerged after that seemed to reinforce the predictions made by Huntington (1993) regarding the clash of civilizations, especially between Islamic and western civilizations. According to Huntington, the end of the cold war will pose a new threat to the world, and the threat does not originate from the conflicts between ideologies or between social classes, or between rich and poor groups, but from cultural differences. As Huntington points out below:

"It is my hypothesis that the fundamental source of conflict in this new world will not be primarily ideological or primarily economic. The great divisions among humankind and the dominating source of conflict will be cultural. Nation states will remain the most powerful actors in world affairs, but the principal conflicts of global politics will occur between 
nations and groups of different civilizations. The clash of civilizations will be the battle lines of the future." (Huntington, 1993:1).

Based on this statement, Huntington argued that the era after the cold war would be marked by conflicts between civilizations. According to him, communities in the world would be divided into human groups based on their respective cultural boundaries and each culture has different values. Thus there would be no universal civilization. He stressed that future conflict would be cultural and religious differences.

According to Huntington Islam is the most problematic culture. Arabs, for example, have no attachment to the state but their religion. Their culture is not friendly to external cultural values, especially the west, such as pluralism, individualism, and democracy. According to Huntington, the clash between civilizations will occur due to several factors. First, the differences between civilizations are not only real but also fundamental. Civilization is different from others because of history, language, culture, traditions, and most importantly religion. People who come from different civilizations will have different views about, for example, the relationship between individual and God, other individuals as well as relationships between parents and children, or husband and wife, or relationships between groups, societies,and countries.

Second, the world becomes increasingly narrow. Interactions between people from different civilizations have increased that led to civilization-consciousness about the similarities but also differences which in turn strengthens the sense of difference and ultimately leads to hostility as conflicts between civilizations in the past. Third, the processes of economic modernization and social change that occur throughout the world result in people becoming separated from their local identities. This process also causes the nation-state as a source of identity to weaken and disappear replaced by the religion which often appears in the form of fundamentalist movements. In many countries, those involved in this religious fundamentalist movement are young people, educated, middle class, and professional to business people.

Fourth, amid western culture domination, awareness arises in non-western societies to return to the roots (Briandana, 2019; Sulistyo, 2018). Western culture is currently at the peak of dominance dealing with non-western societies who have an increasingly strong desire and resources to shape the world in non-western ways.

\subsubsection{Western Democratic Values}

Democracy emerged gradually and was driven by a variety of major events from the signing of the Magna Carta in 1215, to the emergence of the French and American Revolutions in the 18th century. It was only in the 20th century that the notion of democracy was applicable, and became a 'normal' form of government in various countries of the world (Sen, 1999). In a democratic society, the principle of accountability binds public officials to be accountable to the people who elect them for the decisions and actions they take (Anderson, 1981; Bullock, 2000; Cegala, 1981)

Besides, the principle of transparency requires openness to every decision and action of government officials, especially if there are public questions about government policy. In this case, the public has the right to gain access to information about the decisions and actions of the government (Chen \& Starosta, 1986; Johnson, 1987; Kipnis, 1976). Accountability and transparency are two very important ideas in democratic governance. Without accountability and transparency, there will be no democracy. Besides, elections and the principle of people's will are meaningless, and the government becomes authoritarian and only concerned with certain groups (Moberg, 2001; Norris et al, 2011; Tedeschi, 1990).

\subsubsection{Islamic Political Values}

The Islamic legal system called Sharia (شريعة) is the source that determines the behavior or actions of most Muslims everywhere, especially in Islamic countries. In this case, there are two sources of Sharia: the Quran, the holy book of Islam and the Hadith (the words and habits of the Prophet Muhammad). Muslims accept the Koran as God's words and Sharia as the regulator of society and everyday life. Sharia regulates many aspects of the Muslims life, both spiritual, or the relationship between the individual and his God, and secular life including criminal, political, economic and also personal issues, for example, how women should dress (Homa, 2016; Norris \& Inglehart, 2011).

The teachings contained in Sharia are often seen to conflict with what westerners consider to be democratic principles. For certain Islamic political groups, the form of the state is not very important compared to the application of Sharia. This is because the Quran does not mention a particular form of state or a certain system of government that must be developed by Muslims but above all Sharia must be obeyed (Triandis, 2006). People often hold that Sharia is not in line with the principles of western democracy because it provides restrictions on, for example, freedom of speech, women's rights and the rights of minorities. Such rights are highly respected by western democracies. Based on this view, Sharia is often seen as an obstacle to introducing Western democratic values in the Islamic world.

\subsubsection{Islamic Hijab and Religiosity}

Symbols play an important role in one's mental life both in personal and social activities. Each symbol consists of face value and a hidden value. Religious symbols give sacred properties to those who show them. This means that the sacred nature that arises from religious symbols may give those who demonstrate it the strength in their daily social environment. Their presence showing religious symbols becomes very strong in social life.Those who have the habit of displaying religious symbols are often referred to as religious people. In this case, religiosity is a term in social science that is used to indicate, "the condition of being religious to the degree to which one believes and is committed to their chosen faith or belief system" (Allport \& Ross, 1967). Thus religiosity is a condition of someone religious in the degree to which a person believes and has a commitment to the chosen belief system.

The use of religious clothing and symbols is an important form of religious identity expression (Kulenovi, 2006). Hijab as a 
symbol, as part of Muslimah clothing, serves to show the religiosity of the individuals who wear it. Hijab users want to show that they understand the religious provisions as stated by the majority of scholars that wearing a hijab is obligatory for Muslim women. The hijab also serves to show the commitment of Muslim women to religion while enhancing their spiritual life. The use of the hijab also serves to show open to the public an attitude of affirmation of self-identity that they are good Muslimahs (Zwick, 2006).

Based on the literature discussed above, this research builds on Huntington's argument that religious differences are a source of clash of civilizations. A religious community basically will choose a leader who comes from the same religion. But if religious people choose leaders who come from different religions, there will be a clash of civilizations. This study intends to examine the level of conflict between the democratic values and the Islamic values that take placeamong religious Muslim women in the Jakarta Gubernatorial Election in 2017 based on the choice between Ahok (Chinese Christians) and other Muslim candidates.

\subsection{Research Question}

Based on the above discussion and by borrowing Huntington's thesis on the clash of civilizations, this study aims to measure the clash of civilization between the religious Muslims women who perceived the incumbent Chinese governor as achiever against the western democratic values represented by the non-Muslim governors in the Jakarta Gubernatorial Election 2017. The question raised in this study is: What is the level of clash of civilization among religious Muslim women in Jakarta against non-Muslim governors in the 2017 DKI Jakarta Election.

\section{Methods}

This study aims to measure the attitude of religious Muslim women towards non-Muslim leaders namely the Governor of Jakarta, Basuki Tjahaya Purnama, or popularly called Ahok who fought to win the hearts of the people of Jakarta so that he could again serve as governor in the Jakarta Gubernatorial Election in 2017. The achiever Ahok was an incumbent who comes from minority groups, Christian and Chinese descent. The chosen research sample was religious Muslim women in Jakarta. The reason for choosing women in this study is because of the easiness in identifying the religious Muslim women in terms of a symbol than men. Religious Muslim women are more easily identified based on the clothes they wear, wearing hijab or headscarves.

This study also aims to find out whether religious Muslim women in Jakarta rated Ahok as a successful or unsuccessful governor in his first term? In case they rated him as successful, then they would be asked their political choices in the DKI Jakarta Gubernatorial Election in 2017. Will they vote for Ahok or not? The method used in this study is a survey with a questionnaire accompanied by a structured interview. The sample was chosen purposively with the following criteria: (1) Muslim women aged at least 17 years; (2) Wearing the hijab; (3) Domiciled in Jakarta and having a Jakarta identity card.

As discussed earlier, the number of religious Muslim women in Jakarta who held views that Ahok was successful in leading Jakarta butthey rejected him for re-election would be an indicator of the level of civilizations clash. The more respondents who have this kind of assessment, the higher the clashlevel measured on the following five clash level:Very high ( $80 \%$ - 100\% rejected); High (60\% - 80\% rejected); Moderate (40\% - 60\% rejected); Low ( $20 \%$ - 40\% rejected); Very low $(0 \%-20 \%$ rejected).

\section{Research Results and Discussion}

This study asked the respondents to answer two questions followed by short interviews: 1) "In your opinion, was Ahok successfully carrying out his duties as Governor of Jakarta?" Base on the first response, if the answer is 'yes' so the second question comes up: "Will you vote for Ahok as Governor in the 2017 Jakarta Gubernatorial Election?"The answers of the first question can be seen in Table 1.

\begin{tabular}{|c|c|c|}
\hline Successful Rate & Frequency & $\mathbf{\%}$ \\
\hline Very successful & 25 & 5,7 \\
\hline Successful & 276 & 62,7 \\
\hline Neutral & 88 & 20 \\
\hline Unsuccessful & 46 & 10,5 \\
\hline Very unsuccessful & 5 & 1,1 \\
\hline Total & 440 & 100 \\
\hline
\end{tabular}

Table 1: "In Your Opinion, Was Ahok Successfully Carrying Out His Duties as Governor of Jakarta"

Based on the data in Table 4.1, some 440 respondents answered the above questions, and it was found that the majority, or as many as 68.4 percent of respondents, said Ahok was successful or very successful in carrying out his duties as Governor of Jakarta. Some 11.6 percent said they were unsuccessful or very unsuccessful and as many as $20 \%$ said neutrally.

The second question: "Will you vote for Ahok as Governor in the 2017 Jakarta Election?" The answers obtained are shown in Table 2. 


\begin{tabular}{|c|c|c|}
\hline Category & Frequency & $\mathbf{\%}$ \\
\hline Yes & 185 & 36,8 \\
\hline No & 245 & 48,7 \\
\hline Don't know & 73 & 15,5 \\
\hline Total & 503 & 100 \\
\hline
\end{tabular}

Table 2: "Will You Vote for Ahok as Governor in the 2017 Jakarta Gubernatorial Election"

Based on Table 2 as many as 503 respondents answered the question: "Will you vote for Ahok as Governor in the 2017 DKI Jakarta Election?" And based on the data in Table 2 it was found that as many as 48.7 percent of respondents said they would not vote Ahok as the Governor in the elections in 2017. As many as 36.8 percent said they would vote for Ahok, and as many as $14.5 \%$ said they did not know.

In addition to asking respondents questions and producing research data as presented above, the researcher also conducted interviews with respondents about their views of Ahok. In this interview, respondents were asked to explain their reasons why they held that Ahok was successful or unsuccessful in developing Jakarta and why they decided to vote or not vote for Ahok in the election.

\subsection{Those Who Refused}

According to a respondent, Ahok managed to fix Jakarta. "Because he has produced KJP, then (he) has greened Jakarta. So far, there have never been any places to sit, there are no parks everywhere, now when I go to Jakarta, walk the term every few meters, there are seats for resting, and next to it there are trash cans arranged neatly even though not all of them perfect, that's what I know all this time." But he refused to choose Ahok: "At first, I always supported Ahok from the first time, but I'm sorry because yesterday's incident, even though I am also a layman, but I am a Muslim, I am very disappointed, even though I don't know one hundred percent. I'm just saying that my religion is not stained or insulted, just yeah I'm just disappointed over the events of yesterday. They said there are some problems are the point."

According to other respondents, Ahok successfully led Jakarta. "The road is clean, and there are no illegal charges," he said. But he plans not to elect Ahok: "Because in my religion, it is not permissible to choose a leader outside of my religion." According to a respondent, Ahok succeeded in carrying out his duties because he saw street vendors already getting organized, there were already many modern markets, health facilities. Also now the use of BPJS also quite good as it was found in the Puskesmas. Besides, cleanliness has also begun to be good because there are already many orange troops so there is not much garbage piled up. But when asked whether he would vote for Ahok in the 2017 elections? He answered: "Hmmm, I still doubtful if I want to choose Ahok or not. Maybe at work, he's good at everything. But, I judge Ahok had arrogant attitude, in my opinion. But, if for example as long as he works and his work is quite good, yes, I agree, I just don't like his character, maybe that's too arrogant."

\subsection{Those Who Vote}

According to a respondent who supported Ahok, during his time as Governor, Ahok's work program was very helpful for his family in paying for their children's education because of the Jakarta Smart Card (KJP), which could help him in buying various necessities. "Like for example clothes, school clothes, school books, it can also be spent at the supermarket but just to buy milk," he said. Next according to him, he will choose Ahok in the 2017 elections: "God willing, still choose him. Well because in my opinion, he is good at his job, firm, disciplined, although many do not like him ".

Another respondent said Ahok had successfully led Jakarta. According to him, Ahok was strict with anyone, even though they were of different religions, but Ahok built places of worship for Muslims, mosques in various villages or regions. He said he would choose Ahok because there was rarely a firm leader and succeeded in his performance. According to a respondent, he was very pleased with Ahok's honest, trustworthy, decisive performance, and he wanted to choose Ahok again because he wanted Jakarta to be better, cleaner and safer than in previous years. "Surely I (will) choose Ahok as the Governor of DKI Jakarta," he said steadily.

Another respondent said: "In my opinion, yes yes, yes, he succeeded, but with that incident ... so it didn't look good, if he was taking care of the DKI it was good enough, for me. Because of this incident, he became less good, but I'm also not sure. But when asked whether he would vote for Ahok, he replied: "Yes, yes, I will, because he was good to take care of Jakarta."

One respondent said that he would vote for Ahok because during his tenure as governor his work was real and many things had changed in Jakarta. "It's better, Jakarta," he said. According to him, Ahok has reflected a good leader for Jakarta because his people like hard work and detail in his work, and although nothing is perfect, it can be seen from the way he works that Jakarta has changed.

According to a respondent, Ahok succeeded in carrying out his duties based on evidence of Ahok's work so far as the Governor of Jakarta. "For example, transportation in Jakarta is better than before, and also the Pluit reservoir is clean. Also, flats that have been neatly built so that the poor can live there."He said he would vote for Ahok in the 2017 elections because he saw Ahok's work as evidence so far compared to previous governors.

\subsection{Clash of Civilizations}

As discussed above, Huntington's argument that the world community will be divided into groups based on cultural boundaries and each culture has different values. He stressed that the main conflict axis in the future is cultural and religious differences. According to Huntington, the differences between civilizations are not only real but also 
fundamental. Civilization is different from other civilizations because of many factors but the most important is religion. People from different civilizations will have different views about many things. These differences are products that have been formed for centuries and will not be easily lost.

The difference does not always mean conflict, and conflict does not always mean violence. In history, differences between civilizations have led to conflicts, violence, and ideological conflicts. In this study, obtained data regarding the acceptance of governor Ahok among Jakartan Muslims showed that almost 70 percent of religious Muslim women recognized Ahok's success as a governor but, using the same respondents, as many as 48.7 percent of respondents said they would not vote for Ahok in the Jakarta gubernatorial election in 2017.

As explained above, the number of religious Muslim women who viewed Ahok as a successful leader, but at the same time declared that he was not eligible for re-election should an indication of the clash of civilizations. The more respondents with kind of assessment, the higher the clash of civilization level will be. This study found that as many as 48.7 percents of respondents would not vote for Ahok in the Jakarta gubernatorial election even though they acknowledged his success as governor. Thus the number of religious Muslim women who experienced a clash of civilizations in Jakarta ahead of the 2017 Jakarta Election was 48.7\%. As the scale of clash of civilizations has been made, the amount of 48.7 percent is on a scale of between $40 \%$ - $60 \%$ which means a moderate clash level.

\section{Conclusion}

Samuel Huntington believes that the world community will be divided into groups based on their respective cultural boundaries and each culture has different values. He stressed that the main conflict axis is cultural and religious differences. This study found that some 70 percent of religious Muslim women in Jakarta recognized Ahok's success as a governor but, using the same respondents, some 48.7 percent said they would not vote for Ahok. So, it can be concluded that almost 50\% of respondents would not elect Ahok as Governor in the 2017 election. The number of religious Muslim women who experienced a clash of civilizations was $48.7 \%$ which means a moderate level of impact.

\section{References}

i. Allport, G. \& Ross, M. (1967). Personal religious orientation and prejudice. Journal of Personality and Social Psychology, 5, 432-443. In Kelly James Bonewell (n.d). Intrinsic and extrinsic religiosity and sexual compulsivity with Christian males: understanding concepts and correlations based on race, age and socioeconomic status and marital status. (A dissertation) Capella University. http:/ / www.kellybonewell.com/

ii. Anderson, N. H. (1981). Foundations of information integration theory. New York: Academic Press.

iii. Briandana, Rizki (2019). Television and National Identity: An Ethnography of Television Audience in the Border of Indonesia-Malaysia. Jurnal Ilmu Sosial dan Ilmu Politik. 23 (1)

iv. Bullock, K (2000)., Challenging Media Representations of the Veil: Contemporary Muslim Women's Re-Veiling Movement, in American Journal of Islamic Social Sciences, Vol. 17, No. 3, 2000, pp. $22-53$.

v. Cegala, D. J. (1981). Interaction involvement: A cognitive dimension of communicative competence. Communication Education, 30, 109-121.

vi. Chen, G. M., \& Starosta, W. J. (1996). Intercultural communication competence: A synthesis. Communication Yearbook, 19, 353-383.

vii. Homa Khaleeli (7 May 2016). "Sadiq Khan's victory won’t end Islamophobia, but it offers hope". The Guardian.

viii. Huntington, Samuel P. (1993). The Clash of Civilizations. Foreign Affairs, 72:3, pp. 22-49

ix. Huntington, Samuel P. (2002) The Clash of Civilizations and the Remaking of World Order. The Free Press ed., London.

x. Johnson, R. D. (1987). Making judgment when information is missing: Inferences, biases, and framing effects. Acta Psychologica, 66, 69-82.

xi. Kipnis, D. (1976). The powerholders. Chicago: University of Chicago Press.

xii. Kulenovi, T., A Veil (Hijab) as a Public Symbol of a Muslim Woman Modern Identity, in Collegium Antropologicum, Vol. 30, No. 4, 2006, pp. 713-718.

xiii. Moberg, P. J. (2001). Linking conflict strategy to the five-factor model: Theoretical and empirical foundations. The International Journal of Conflict Management, 12(1), 47-68.

xiv. Norris, Pippa \& Inglehart, Ronald (2011). Sacred and Secular: Religion and Politics Worldwide, Cambridge University Press

xv. Sen, Amartya Kumar (1999). Democracy as a Universal Value. Journal of Democracy. Vol 10. Issue 3. Https:/ / www.journalofdemocracy.org/ articles/ democracy-as-a-universal-value/

xvi. Sulistyo, P. B (2018). Teenagers' Preferences, Creations and Participation in Vlogging Activities (Case in the City of Jakarta, Indonesia). International Journal of Scientific and Research Publication. 8 (8)

xvii. Tedeschi, J. T. (1990). Self-presentation and social influence: An interactionist perspective. In M. J. Cody and M. L. McLaughlin (Eds.), The psychology of tactical communication (pp. 301-323). Clevedon, England: Multilingual Matters.

xviii. Triandis, H. C. (2006). Culture and conflict. In L. A. Samovar, R. E. Porter \& E. R. McDaniel (Eds.), Intercultural communication: A reader (pp. 22-31). Belmont, CA: Wadsworth.

xix. Zwick, D.; C. Chelariu (2006). Mobilizing the Hijab: Islamic Identity Negotiation in the Context of a Matchmaking Website, in Journal of Consumer Behavior, Vol. 5, No. 4, 2006, pp. 380-395. 